\title{
Typology of Fala Kanci House as a North Maluku Traditional House
}

\author{
Endah Harisun \\ Programme of Study in Architecture, Faculty of Engineering, Khairun University, Ternate, \\ Indonesia \\ Corresponding Author: endah.harisun@unkhair.ac.id
}

\begin{tabular}{ll}
\hline Keywords: & Abstract \\
Fala kanci, Traditional & The Indonesian people are very rich in tradition and culture. One of \\
house, Typology & the traditions and culture that still exists today is a traditional house. \\
& This traditional house has the uniqueness and characteristics of each \\
& region. Buttoned traditional house (fala kanci) is a traditional North \\
& Maluku house spread throughout North Maluku. Button house has \\
& unique characteristics, namely building construction. With building \\
& construction using wood as a building structure starting from beams \\
& on foundation, columns and beams which all bound together using \\
& traditional wooden pegs and joints. In this modern era the existence \\
& of traditional houses is increasingly rarely found. This research it is \\
& hoped that it can open up the horizons of thought about the existence \\
& and uniqueness of traditional houses owned by the people of North \\
& Maluku in general and the people of Ternate in particular. The \\
typology approach by comparing four traditional houses of fala kanci \\
was chose from four different villages, so that it can be conclude \\
about the characteristics of fala kanci traditional houses in Ternate. \\
These characteristics are in the form of building facades, floor plans, \\
walls, foundations and construction of fala kanci traditional houses. \\
Fala Kanci is also an earthquake resistant building because of the \\
uniqueness of its building frame.
\end{tabular}

DOI: https://doi.org/10.26905/lw.v12i2.4005

@ 2017 The Authors. Published by GKAK UNMER Malang

$\begin{array}{llll}\text { Article History } & \text { Received } & \text { : } & \text { Feb 24, 2020 } \\ & \text { Accepted } & : & \text { June 26, 2020 } \\ & \text { Published } & : & \text { July 15, 2020 }\end{array}$

\section{INTRODUCTION}

Various traditional architecture in Indonesia is a legacy of ancestors who have a very broad cultural arts and different from one another. One of them is a traditional (Mukhtar \& Pangarsa, 2013). Traditional architecture is architecture that is still alive and continues to be preserved from one generation to another in sequence. Because of the progress of time and the difference in time, traditional architecture is also changing (Prasetya, 2007). 
Currently, traditional houses are experiencing challenges for homeowners whether to preserve traditional buildings or make changes from the original. The phenomenon that occurs today is restoring traditional forms by preserving traditional buildings today. By restoring the current traditional forms, traditional houses will lose their meaning (Tarigan, 2016).

The activity of preserving traditional architecture is not only for aesthetic satisfaction, but also must consider the direct and indirect impacts of community welfare. To make traditional societies become modern societies, people do not need to replace building materials, which the use can be actualized and has an identity (Pattipeilohy, 2013)

Ternate city is one of the cities in North Maluku Province is an old city that is more than 765 years old and has many historical heritages. These relics are only recorded in various literature books and media as historical stories that do not receive much attention (Harisun \& Quraisy, 2017). One of the relics is the traditional house fala kanci (button house). fala kanci is a traditional house that is spread throughout the North Maluku region. Now the existence of traditional houses fala kanci is rare found along with the destruction of old houses and houses built in contemporary architectural style.

Fala Kanci comes from the local language Fala means "home" and Kanci means "button". Fala kanci is called a button house because the house structure system uses a timber frame structure system that is connected by not using nails, but using a peg as a binding to the building structure. The fala kanci traditional house was the people's house of its time and included cultural heritage buildings because the average age of the fanca kanci house was more than 50 years.

Button house characteristics are define as members of the human body consisting of the head (roof), body (wall) and legs (foundation). According to the custom of the Ternate community, button houses are the result of culture and tradition because the button house is a symbol of brotherhood compared to building construction that is bound to one another by using a peg (nail replacement) as a hold. If one peg is release, all ties in the building blocks and columns will be release to. So they are connected to each other and are one entity.

\section{METHODOLOGY}

The approach taken in this research is descriptive-qualitative by describing the results of the field survey regarding the condition of the research object. While the method used in this study is to trace the typology of the characteristics of fala kanci house.

Typology is a process carried out to study the types of architectural objects and then group them based on similarities in the basic forms and functions of architectural objects (Setyowati, Wulandari, \& Pamungkas, 2014). Because of the unique building construction, this research variable focuses on façade building, floor plans, building roof forms, building construction and building materials. Whereas traditional building objects are chosen based on the age criteria of houses over 50 years old and are scattered in several areas of Ternate. Many buildings still retain the construction of fala kanci house, but in parts of their homes have used new materials such as ceramics and bricks, while houses that have been built for more than 50 years still retain these building materials. 


\section{Typology of Fala Kanci House as a North Maluku Traditional House}

Table 1. The spread of research object houses
Building location
Information
(a). Loto Village
The owner is Mrs. Asfia Haji Ismail and the old of this
(b). Taduma Village building is 51 years based on interviews
(c). Jambula Village
The owner is Mr. Abdullah Hasan and the old of this building is 58 years based on interviews
The owner is Mr. Tamrin Hasyim and the old of this
(d). Sasa Village building is 70 years based on interviews The owner is Mr. Yakub Hadad and the old of this building is 52 years based on interviews

\section{THE TYPOLOGY OF FALA KANCI TRADISIONAL HOUSE}

\section{Building Façade}

According to the Krier in (Santri, 2017), the facade is an important element in architecture that represents the function of the building. The façade of the fala kanci traditional house is dominated by terraces and wooden pillars.

\begin{tabular}{lllll}
\hline \multicolumn{1}{c}{ Description } & Type (a) & Type (b) & Type (c) & Type (d) \\
Building & & &
\end{tabular}

Characteristi - The facade of the building is dominated by a terrace with Lumber CS poles

- The type of building facades in the houses in the Loto and Jambula villages are the same, while the facades of the houses in the villages of Taduma and Sasa begin with the front bedroom next to the terrace

- The building roof model in the three villages is almost the same in the form of a pyramid while the roof of the five houses in Jambula village is in the form of a saddle

- The entire terrace of the house is limited by half a wall about 50 $\mathrm{cm}$ high

\section{Layout}

The plan of the fala kanci house is rectangular with the orientation of the building facing the sea to the east and the mountain to the west.

The plan of the fala kanci house is rectangular with the orientation of the building facing the sea to the east and the mountain to the west.

Table 2. Floor plan typology

\begin{tabular}{ccccc}
\hline Description & Type (a) & Type (b) & Type (c) \\
floor plan form
\end{tabular}




$\begin{array}{ll}\text { Description } & \text { Type }(\mathrm{a}) \\ \mathrm{s} & \text { The house consists of a terrace, living room, family room and kitchen } \\ & \text { WC which is placed separately from the main building } \\ \text { - } & \text { The addition of new space in the back that functions as a kitchen and } \\ & \text { dining room except in house type }(\mathrm{d}) \text { which is still original } \\ & \text { The development of the house with the addition of the number of rooms } \\ & \text { caused by the development of family needs (Tarigan, 2015) } \\ \text { - } & \text { Placement of the bedroom on the right side of the building while the } \\ & \text { living room and family room on the left side and the original building } \\ & \text { composition is KM / WC separate from the main building. }\end{array}$

The procedure for placing a room in a fala kanci house is:

- Terrace (surabi), interpreting the terrace as a shelter for people who pass or function as a shelter/stop for a few moments, for example when it rains they take shelter on someone's terrace;

- The Living Room (foris), it is a place to receive guests and a place to relax;

- Family bedroom (konora bati-bati), they interpret this as a sleeping area that is usually occupied by parents;

- The front bedroom (tomagunaga bati-bati), the front of the bedroom is usually occupied by boys to maintain the security of the house;

- Back room (tomadudu bati-bati), girls' bedrooms are usually behind this due to the diverse needs of women and anticipating unwanted things that can happen. Women's rooms should not be adjacent to the living room where women are very guarded by privacy such as not wearing minimal clothing when they finish bathing and going to her room;

- Bathroom (Dum bati), the bathroom is located separately from the building because according to the community the house is a holy place that must be kept away from dirty things so it must be separated.

\section{Building Roof Forms}

The roof is one of the elements in the building that is important for the tropics. The roof serves as a protector of the main building (Prasetyo et al., 2017). The fala kanci traditional house roof has a unique construction system. In the fala kanci beam house and its construction are interrelated and at first the fala kanci roof is made of dried alang-alang grass. The method of connecting one lumber with another using a peg and then tied with coconut fiber (gumutu). The slope of the roof (suai) is adjusted to the climate of the city of Ternate. The slope of the roof (suai) is adjusted to the climate of the city of Ternate. The rooftop beam that crosses the roof and functions to channel rain down is called mafana.

Table 3. Typology of room form

\begin{tabular}{ccccc}
\hline $\begin{array}{c}\text { Descriptio } \\
\mathrm{n}\end{array}$ & Type (a) & Type (b) & Type (c) & Type (d)
\end{tabular}

roof form
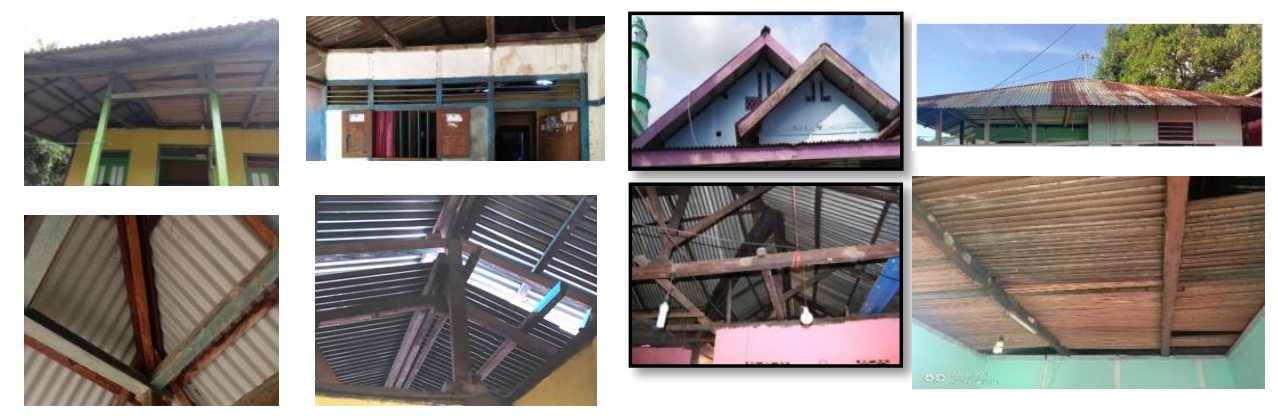


\section{Typology of Fala Kanci House as a North Maluku Traditional House} Endah Harisun

\begin{tabular}{lll}
\hline $\begin{array}{c}\text { Descriptio } \\
\mathrm{n}\end{array}$ & Type (a) & Type (b) Type (d) \\
Characte & - All roofs use fala kanci construction \\
ristics & - All roofing materials have been changed using zinc wave material \\
& - All of houses do not use ceilings only on type (d) houses that use chin \\
& (gaba-gaba) stems, a type of sago leaf. \\
& Sago trees are plants that mostly grow in eastern Indonesia including \\
& Maluku, North Maluku and Papua (Harisun, Conoras, \& Saifudin, 2019)
\end{tabular}

\section{Building Wall Material}

Before steel and iron were discovered, in the past people built houses using timber frame or bamboo as building structures, the connection system to lumber and bamboo used a traditional bonding system with coconut fibers (ijuk), pegs and nails. During the Dutch and Japanese occupation era, technology was introduced in Indonesia. The components of the bamboo pair wall begin to be combined with stucco where bamboo is used as reinforcement (Muliawan, 2012).

Description
Type (a)

Characte - The walls of a traditional fala kanci house use woven bamboo (pitate) as a ristics reinforcement and then coated with a mixture of lime and egg white as an adhesive. Lime is made of stone which is burned to dust usually people call it kalero

Bamboo has a fairly high tensile strength (up to 1,280 kg / cm2), this tensile strength can be juxtaposed with the tensile strength of steel. In addition, bamboo has a high elasticity. Bamboo structure has a high resistance to wind or earthquake (B, 2011)

The footing of the Fala Kanci House

Before steel and iron were discovered, in the past people built houses using lumber or
Description Type (a)
Type (b) Type (c) Type (d)
Wall
Constructi
on
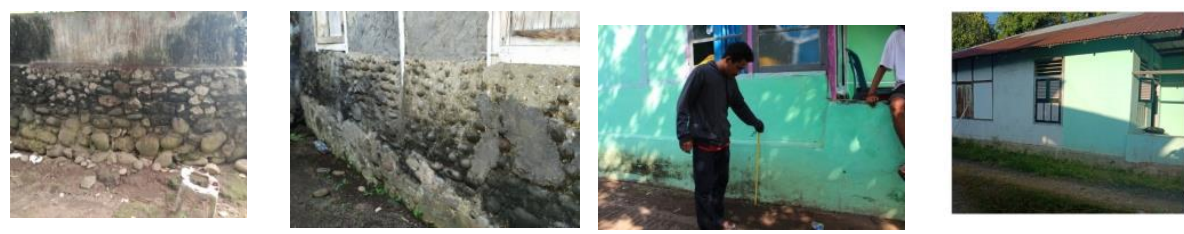
Characte - The footing is - The footing
- In fala kanci
- The material used 


\begin{tabular}{|c|c|c|c|c|}
\hline $\begin{array}{l}\text { Description } \\
\text { ristics }\end{array}$ & $\begin{array}{l}\text { Type (a) } \\
\text { made of a } \\
\text { mixture of } \\
\text { stone, sand } \\
\text { and kalero. The } \\
\text { centre of the } \\
\text { wall is a } \\
\text { reinforcement } \\
\text { of bamboo } \\
\text { slats. } \\
\text { - using river } \\
\text { stone and } \\
\text { coral } \\
\text { construction }\end{array}$ & $\begin{array}{l}\text { Type (b) } \\
\text { structure of } \\
\text { the main } \\
\text { material uses } \\
\text { beach stones } \\
\text { which are } \\
\text { then arranged } \\
\text { using lime } \\
\text { (kalero) as an } \\
\text { adhesive, } \\
\text { arranged up } \\
\text { to half a wall }\end{array}$ & $\begin{array}{l}\quad \text { Type (c) } \\
\text { traditional } \\
\text { houses, the } \\
\text { footing } \\
\text { structure uses } \\
\text { river stone } \\
\text { footing which } \\
\text { are generally } \\
\text { used in other } \\
\text { residential } \\
\text { buildings. The } \\
\text { process differs } \\
\text { only in the } \\
\text { material used, } \\
\text { which is } \\
\text { arranged using } \\
\text { a mountain } \\
\text { stone and glued } \\
\text { together using } \\
\text { kalero as an } \\
\text { adhesive. }\end{array}$ & $\begin{array}{l}\quad \text { Type (d) } \\
\text { is based on the } \\
\text { results of the } \\
\text { interview, the } \\
\text { footing is prepared } \\
\text { using a mountain } \\
\text { stone and glued } \\
\text { with lime (kalero) } \\
\text { which is now } \\
\text { replaced with } \\
\text { cement. kalero is } \\
\text { taken from sea } \\
\text { corals and then } \\
\text { dried in the sun } \\
\text { and then burned } \\
\text { with coconut } \\
\text { trunks then } \\
\text { burned until } \\
\text { charred into ash } \\
\text { then rinsed with } \\
\text { salt water. }\end{array}$ \\
\hline
\end{tabular}

Based on the table above, it can be seen that the footing of the whole building uses a mixture of stone and lime (kalero) as cement replacement adhesive.

As is known that the main ingredients forming cement are lime $(\mathrm{CaO})$, silica $(\mathrm{SiO})$, alumina (Al2O3) and a little magnesia (MgO), and sometimes added with alkali (Kurniawan et al., 2016).

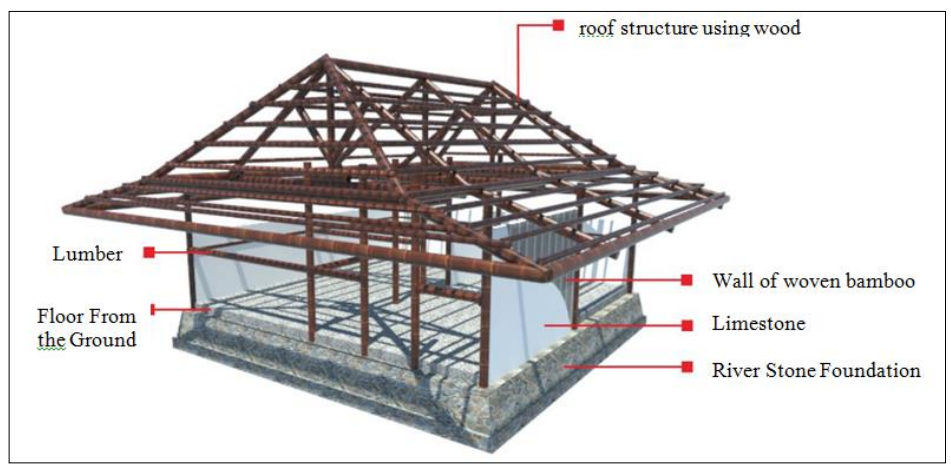

Figure 1. Fala kanci house construction

\section{Local Wisdom of Traditional Architecture Fala Kanci House}

Traditional architecture is architecture that was created from generation to generation and is often called regional architecture. Traditional architecture is the embodiment of people's daily traditions, culture and people's beliefs (Usop, 2011),

The traditional architecture of North Maluku has a distinctive shape as in other regions in Indonesia. The traditional architecture of North Maluku consists of traditional houses, dwellings, meeting halls and others. The naming of these houses is based on the construction system, the shape of the roof, and the dominant materials used such as fala 


\section{Typology of Fala Kanci House as a North Maluku Traditional House \\ Endah Harisun}

gaba-gaba (houses whose walls are made of sago leaves), fala kanci (houses with a wooden frame structure connected by not using nails), folajikosesurabi (house with a roof terrace).

Fala kanci house is the result of hereditary knowledge from grandfather to children and so on. The called buttoned house because this house uses a system of lumber frames that are interconnected and without using a rigid connection such as using nails. Have lightweight roof and wall materials, making this building earthquake resistant. According to (Sulaeman, 2012), the North Maluku region is one of the areas in Indonesia that is prone to earthquake disasters. Regionally the North Maluku region is at the boundary of the meeting of the three main plates namely the Eurasian Plate, Indo-Australia, and the Pacific. Since 1858, the North Maluku region has experienced an earthquake 16 times. Recently an earthquake of 7.2 on the Richter scale struck South Halmahera Regency.

Until now, button houses still be found in almost all areas of North Maluku. Local wisdom created in this building can be seen in the selection of building materials which are natural materials before being replaced with manufacturing materials such as roofs made of straw leaves or reeds replaced with zinc. Likewise with the layout that divides the rooms of boys and girls and the placement of separate toilets with the main house.

\section{CONCLUSION}

The existence of fala kanci traditional houses in Ternate city is rarely found. At the times, very influential in the development of traditional houses in the North Maluku region. The result that can be concluded through the typology approach for the building under study is that most of the houses are still original, with the main construction maintained. Some houses have changed the shape of house plans due to the increasing number of families so that the need for beds has also increased. Increased space requirements can be seen in houses fala kanci in the villages of Loto, Taduma, and Jambula. The addition of the room was followed by a change in wall material which was once a traditional house wall of fala kanci using bamboo matting (pitate) as a reinforcement and then coated with a mixture of lime and egg white as an adhesive, now it has used brick material, but building construction is still maintained. Only at the button house (fala kanci) in Sasa village, the house layout was maintained as before.

Changes also occur in the roof covering material. Previously, at the beginning of the construction of the button house (fala kanci), they still used sago tree leaves or dried reeds, now they have been replaced by zinc waves.

Local wisdom that is still maintained in the traditional fala kanci house is the division of the function of the house plan that is adjusted to the Islamic Sharia. Islamic Sharia practiced by almost all North Maluku people in general and the community. Ternate in particular. The typology of the floor plan that places the women's room at the back of the floor plan, can be found throughout the button house building (fala kanci). by using a wooden structure construction system with structural connections fastened to a peg without using nails, making the button housing (fala kanci) resistant to lateral forces generated by earthquake loads. This makes the button house (fantasy) respond to the earthquake. As is known that the North Maluku region is an earthquake-prone area, but the existence of button houses (fala kanci) can still be seen today.

The challenge now is to preserve the survival of the North Maluku traditional house itself. With the increasing needs of life and the rapid development of architecture, it is 
hoped that the role of the government will be able to maintain the preservation of button houses (fala kanci). Activities that can be carried out by the government are providing subsidies to homeowners in their household needs, taking over home repairs and establishing button houses (fala kanci) as heritage buildings.

\section{References}

B, A. J. R. dan I. S. B. (2011). Bambu Sebagai Bahan Konstruksi Rangka Dinding Rumah Tembok Suku Bajo di Desa Kabalutan dalam Upaya Perbaikan Hunian. Unity Jurnal Arsitektur, 1(2), $80-86$

Harisun, E., Conoras, M. A. M., \& Saifudin, H. (2019). Tipologi Konstruksi Rumah Tradisional “Fala Gabagaba" sebagai Perwujudan Bangunan Hemat energi. Journal Of Science And Engineering, 2(1), 19-24.

Harisun, E., \& Quraisy, S. (2017). Arsitektur Kolonial pada Bangunan Rumah Gubernur Jenderal VOC di Benteng Oranje Ternate. 178-186.

Kurniawan, A., Afrizal, Y., Gunawan, A., Limun, K., Jurusan, D., \& Sipil, T. (2016). Pengaruh Pemanfaatan Pecahan Terumbu Karang Sebagai Pengganti Agregat Halus Terhadap Kuat Tekan Beton. Inersia, 8(2).

Mukhtar, M. A., \& Pangarsa, G. W. (2013). Struktur Konstruksi Arsitektur Tradisional Bangunan Tradisional Keda Suku Ende Lio di Permukiman Adat Wolotolo. Jurnal RUAS, 11(1), 17-28.

Muliawan, I. W. (2012). Aplikasi Teknologi Bambu Semen Sebagai Dinding Di Desa Penglipuran Kabupaten Bangli. Metana, 8(01), 18-31.

Pattipeilohy, J. . (2013). Arsitektur Tradisional Tidore Kepulauan. Jurnal Penelitian, 6(5), 62-91.

Prasetya, L. E. (2007). Adaptation and Sustainable Architecture; Manggaraian Traditional Architecture in age of Globalization 1.1-9.

Prasetyo, Y. H., Astuti, S., Perumahan, L., Panyawungan, J., Wetan, C., Bandung, K., ... No, U. (2017). NUSANTARA DALAM REGIONALISME Tropic Climate Form of Nusantara Traditional Architecture's Expression in Regionalism. 12(2), 80-93.

Setyowati, T. I., Wulandari, L. D., \& Pamungkas, S. T. (2014). Tipologi Fasade Bangunan di Jalan Kawi Atas Kota Malang. Jurnal Mahasiswa Jurusan Arsitektur Universitas Brawijaya, 2 No. 2.

Sulaeman, C. (2012). Model Intensitas Gempa Bumi di Maluku Utara Earthquake Intensity Model in North Maluku. 3(2), 79-88.

Tarigan, R. (2015). Tantangan Pelestarian dan Perubahan terhadap Manfaat Ruang Tradisional Akibat Pengaruh Kegiatan Industri Rumah Tangga. Jurnal Arsitektur Komposisi, 11 no.2, 77-84.

Tarigan, R. (2016). Arsitektur Vernakular Berbasis Arsitektur Tradisional: Menuju Arsitektur Lokal Yang Berkelanjutan Studi kasus: Rumah di Desa Karangmalang, Kabupaten Kudus. Tesa Arsitektur, 14, 23-32.

Usop, T. B. (2011). Kearifan Lokal Dalam Arsitektur Kalimantan Tengah. 6, 25-32. 